\title{
Antibacterial Activity of Various Extracts of Averrhoa bilimbi against Multidrug Resistant Bacteria
}

\author{
Muhammad Evy Prastiyanto*, Fandhi Adi Wardoyo, Wildiani Wilson, Sri Darmawati \\ Department of Medical Labolatory Technology, Universitas Muhammadiyah Semarang, Indonesia \\ *Email: evy_prastiyanto@unimus.ac.id \\ Submitted: 28 February 2020. Revised: 18 April 2020. Accepted: 1 June 2020
}

\begin{abstract}
The multi-drug resistance (MDR) bacteria is a global health problem that causes high mortality every year. Therefore, novel antibacterial agents are needed from natural biological sources. This research aimed to investigate the antibacterial activities of various crude extracts of Averrhoa bilimbi against MDR bacteria. The antibacterial activity was calculated based on the use agar well diffusion assay and the minimum bactericidal concentration (MBC) using Mueller-Hinton broth in a microdilution method. Bacteria from wells were subcultured using inoculating loop onto a 5\% sheep BAP. The best antibacterial activity, calculated as the most widely inhibitory zone and the smallest MBC values. The ethanolic extract showed antibacterial activity against the all MDR bacterial test in the agar well diffusion assay (10-14.5 mm inhibition diameter). The MBC of water extract against ES $\beta \mathrm{L}+\mathrm{CR}$ Pseudomonas aeruginosa showed the best antibacterial activity $(12.5 \mathrm{mg} / \mathrm{mL})$. The fruit of bilimbi was shown to be potentially developed as antibacterial agents, especially for MDR strains. Further in vivo research and discovery of action mode are needed to shed light on their antibacterial effects. This study can provide new information about the benefits of bilimbi as a source of natural antibacterial againts MDR-bacteria.
\end{abstract}

Key words: Averrhoa bilimbi; Antibacterial activity; Minimum Bactericidal Concentration; Resistance bacteria; Secondary metabolites

How to Cite: Prastiyanto, M. E., Wardoyo, F. A., Wilson, W., \& Darmawati, S. (2020). Antibacterial Activity of Various Extracts of Averrhoa bilimbi against Multidrug Resistant Bacteria. Biosaintifika: Journal of Biology \& Biology Education, 12 (2), 163-168

DOI: http://dx.doi.org/10.15294/biosaintifika.v12i2.23600

\section{INTRODUCTION}

The antibiotic resistant bacterial strains have been a menace to public health globally. Particularly, multi-drug resistant (MDR) bacterial strains remain a serious cause of concern since they cause treatment failures and impose huge economic burdens especially in developing countries (Ballani and Babby, 2016). MDR bacteria are the main cause of severe complications in the therapies of contagious diseases and has become a serious problem that causes high mortality every year (Mekes et al., 2019). The MDR bacteria is a global health problem caused by inappropriate use of antibiotics. Patients with infections caused by MDR bacteria have a worse risk due to their difficult treatment and the likelihood of high mortality. Infections caused by MDR bacteria also consume more health-care resources than patients infected with nonresistant strains of the same bacteria (Word Health Organization, 2018). So, novel antibacterial agents are needed from natural biological sources (Valle Jr et al., 2015). Biological antibacterial agents can be obtained from the mushrooms (Prastiyanto et al., 2016), bacteria (Ryandini et al., 2018), bacteriocins (Lestari et al., 2019), and plant (Tillah et al., 2017; Wahyuni et al., 2019). There have been many reports found in the medical literature concerning the significance of traditional medicinal plants as alternatives to antibacterial agents (Akhtar, 2015; Aumeeruddy-elalfi et al., 2015).
Plants is a good source of antibacterial compounds, because of the variety and diversity of the chemical structures of the compounds contained therein (Ngameni et al., 2013). Averrrhoa bilimbi Linn. (bilimbi) also known as belimbing wuluh in Indonesia is one of the medicinal plants that is found in tropical and subtropical countries and useful as a medicine, such as antidiabetic (Ahmad et al., 2019), hepatoprotective (Dnyaneshwar et al., 2010), anticancer, and antithrombotic agent (Ali et al., 2014).

Research related to antibacterial activity of bilimbi has been reported. The extracts of bilimbi fruit can inhibit bacteria Escherichia coli ATCC 25922, Pseudomonas aeruginosa ATCC 27853, Salmonella typhimurium ATCC 14028, Staphylococcus aureus ATCC 25923, Vibrio parahaemolytius ATCC 17802 (Seebaluck-sandoram et al., 2019). The fruits and roots extracts of bilimbi were also inhibit Mycobacterium tuberculosis (Mohamad et al., 2011). Research on antibacterial activity of extracts of bilimbi fruits against MDR bacteria have not been reported, so it is necessary to investigate the antibacterial potential of bilimbi fruit extract against MDR bacteria. In this study, we used five variations of bilimbi fruit extracts.

The study on antibacterial activity of bilimbi with various solvent (Methanol, Ethanol, Chloroform, NHexane and water) are expected to provide new information about the benefits of bilimbi. In addition, it also can support the bilimbi as a source of natural antibacterial agent againts MDR-bacteria. The re- 
search aim was to investigate the antibacterial activities of fruit extracts of bilimbi with various solvents against MDR bacteria from clinical specimen.

\section{METHODS}

\section{Plant materials}

Fruits of bilimbi Figure 1 (green, not overly ripe) were freshly picked from a home garden in Kedungmundu, Semarang, Indonesia. The fruits were washed with water to remove all unwanted materials and then rinsed with sterilized distilled water, then dried under sunlight for two days. The dried bilimbi were then milled into fine powder using a milling machine and stored in a sterile airtight container until further use.

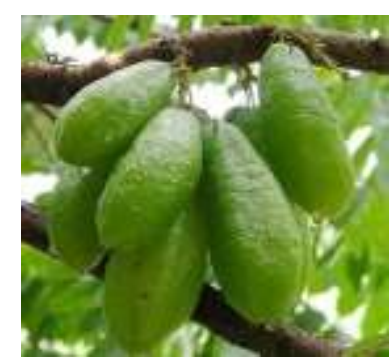

Figure 1. Bilimbi fruits (Averrhoa bilimbi)

\section{Plant extract preparation}

Bilimbi extracts were prepared using the maceration method with various solvents i.e.: methanol, eth- anol, chloroform, N-Hexane and water. One hundred grams of powdered bilimbi was soaked in $300 \mathrm{~mL}$ of each solvent for $24 \mathrm{~h}$ at room temperature and protected from light with shaking. Solvent replacement was done every day. Replacement of solvent was done until the solution became clear with the assumption that there was no active compound contained in the dry powder. The supernatant was filtered through Whatman filter paper No.1 (Whatman). Maceration solutions were concentrated under reduced pressure using a rotary evaporator at $50^{\circ} \mathrm{C}$. The crude extracts were collected and allowed to dry at room temperature.

\section{Bacterial preparation}

The organisms used for in vitro antibacterial screening in this study is summarized in Table 1. MDR bacteria were isolated from patients of the dr. Kariadi Hospital, Semarang City, Indonesia. All isolates were identified and susceptibility patterns were obtained using Vitek ${ }^{\circledR} \mathrm{MS}$ (bioM'erieux, Marcy l'Etoile, France). The bacteria were subcultured overnight $(24 \mathrm{~h})$ at $35 \pm 2{ }^{\circ} \mathrm{C}$ on $5 \%$ sheep blood agar (BAP). The bacterial colonies were homogenized and adjusted to $0.5 \mathrm{McF}$ arland standards $\left(5 \times 10^{8} \mathrm{CFU} / \mathrm{mL}\right)$ using spectrophotometry.

Table 1. The organisms for in vitro antibacterial screening in this study

\begin{tabular}{|c|c|c|}
\hline Species & Source & Antibiotic resistance pattern \\
\hline $\begin{array}{l}\text { ES } \beta \mathrm{L}, K . \text { pneumoniae } \\
\text { ssp pneumoniae }\end{array}$ & $\begin{array}{l}52 / \text { male, } \\
\text { swab wound }\end{array}$ & $\begin{array}{l}\text { Ampicillin, Sulbactam, Cefazolin, Ceftazidime, Ceftriaxone, Cefepime, } \\
\text { Aztreonam, Gentamicin, Sulfamethoxazole }\end{array}$ \\
\hline $\mathrm{ES} \beta \mathrm{L}$, E. coli, & $\begin{array}{l}29 \text { / male, } \\
\text { swab wound }\end{array}$ & $\begin{array}{l}\text { Ampicillin, Sulbactam, Tazobactam, Cefazolin, Ceftazidime, Ceftriax- } \\
\text { one, Cefepime, Gentamicin, Ciprofloxacine, Sulfamethoxazole }\end{array}$ \\
\hline $\mathrm{ES} \beta \mathrm{L}+\mathrm{CRE}$, E. coli, & $\begin{array}{l}2 / \text { male, } \\
\text { pus }\end{array}$ & $\begin{array}{l}\text { Ampicillin, Sulbactam, Tazobactam, Cefazolin, Ceftazidime, Ceftriax- } \\
\text { one, Cefepime, Aztreonam, Ertapenem, Meropenem, Ciprofloxacine } \\
\text { Sulfamethoxazole }\end{array}$ \\
\hline $\begin{array}{l}\mathrm{ES} \beta \mathrm{L}+\mathrm{CRE}, K \\
\text { pneumoniae ssp pneu- } \\
\text { moniae }\end{array}$ & $\begin{array}{l}60 / \text { female, } \\
\text { bronkus }\end{array}$ & $\begin{array}{l}\text { Ampicillin, Sulbactam, Tazobactam, Cefazolin, Ceftazidime, Ceftriax- } \\
\text { one, Cefepime, Aztreonam, Ertapenem, Meropenem, Gentamicin, } \\
\text { Ciprofloxacine, Sulfamethoxazole }\end{array}$ \\
\hline MRSA & $\begin{array}{l}53 \text { / female, } \\
\text { pleura }\end{array}$ & $\begin{array}{l}\text { Benzylpenicillin, Oxacillin, Gentamicin, Ciprofloxacine, Levofloxacin, } \\
\text { Erythromycin, Clindamycin, Tetracycline, Rifampicin, Sulfamethoxa- } \\
\text { zole }\end{array}$ \\
\hline $\begin{array}{l}\mathrm{ES} \beta \mathrm{L}+\mathrm{CR} \text { Pseudo- } \\
\text { monas aeruginosa }\end{array}$ & $\begin{array}{l}41 / \text { female, } \\
\text { sputum }\end{array}$ & $\begin{array}{l}\text { Ampicillin, Sulbactam, Tazobactam, Cefazolin, Ceftazidime, Ceftriax- } \\
\text { one, Cefepime, Aztreonam, Meropenem, Amikacin Gentamicin, } \\
\text { Ciprofloxacine, Tigecycline, Nitrofurantoin, Sulfamethoxazole }\end{array}$ \\
\hline
\end{tabular}

ESßL: extended spectrum beta-lactamase, CRE: Carbapenem-resistant Enterobacteriaceae CR: Carbapenemresistant, MRSA: Methicillin-resistant Staphylococcus aureus

\section{Antibacterial susceptibility sssays}

The antibacterial activity from various extracts of bilimbi was evaluated using agar well diffusion assay (Andleeb et al., 2020). In this method, $100 \mu \mathrm{L}$ of each test organism which was equivalent to a $0.5 \mathrm{McFar}$ - land standard was inoculated on the Muller Hilton Agar (MHA). Then it was spread onto the surface of the agar using a sterilized glass spreader. After 10 minutes of inoculation, the wells were prepared using sterilized steel cork borer ( $1 \mathrm{~cm}$ diameter). Wells were 
made in each plate, out of which five wells were loaded with each extracts $(200 \mu \mathrm{g}$ or $200 \mu \mathrm{L}$ from $1000 \mu \mathrm{g} / \mathrm{mL}$ ). All the plates were then incubated aerobically at $35 \pm 2{ }^{\circ} \mathrm{C}$ for $24 \mathrm{~h}$. Antibacterial activity of the extracts was determined by measuring the diameter of inhibition zone in mm against the test organism.

\section{Minimum bactericidal concentration (MBC) of the bilimbi fruits extracts.}

The MBC of bilimbi fruit extract was determined using Mueller-Hinton broth microdilution (CLSI, 2018). MBC determination was performed by a serial dilution technique using 12-well microtiter plates. Bilimbi fruit extract $(100 \mathrm{~mL})$ was placed into the well/plate. Then, $100 \mathrm{~mL}$ ofbacterial cell suspensions (0.5 McFarland) were placed in each well/plate. Microplates were incubated for $24 \mathrm{~h}$ at $35 \pm 2{ }^{\circ} \mathrm{C}$. The MBC of bilimbi fruit extract was determined following the methods described by Parvez et al. (2019) with slight modifications. The bacteria in wells were subcultured using a $10 \mathrm{~mL}$ inoculating loop onto a $5 \%$ sheep BAP at $(35 \pm 2){ }^{0} \mathrm{C}$ for $16-20 \mathrm{~h}$ incubation. The MBC was defined as the lowest concentration of the extract that did not any growth of bacterial colony on 5\% sheep BAP. Mueller-Hinton broth as negative control. Cefazolin and meropenem were used as positive controls for ESBL-producing bacteria. Cefazolin and tigecycline were used as positive controls for ESBL + Carbapenem resistance (CR), while Sulfamethoxazole and vancomycin were used as positive controls for MRSA

\section{RESULTS AND DISCUSSION}

\section{Antibacterial susceptibility assay}

The antibacterial susceptibility assays were initially performed to determine the antibacterial activities of the various extracts of bilimbi fruit against MDR bacteria, namely, ES $\beta \mathrm{L} K$. pneumoniae ssp pneumonia, ES $\beta \mathrm{L}$ E. coli, ES $\beta \mathrm{L}+\mathrm{CRE}$, E. coli, $\mathrm{ES} \beta \mathrm{L}+$ CRE, K. pneumoniae ssp pneumonia, MRSA, ES $\beta \mathrm{L}+$ CR $P$. aeruginosa. The extract of bilimbi fruit with various solvents (methanol, ethanol, chloroform, nHexane and water) showed inhibition of bacterial growth against some or all of the test organisms (Figure 2 and Table 2).

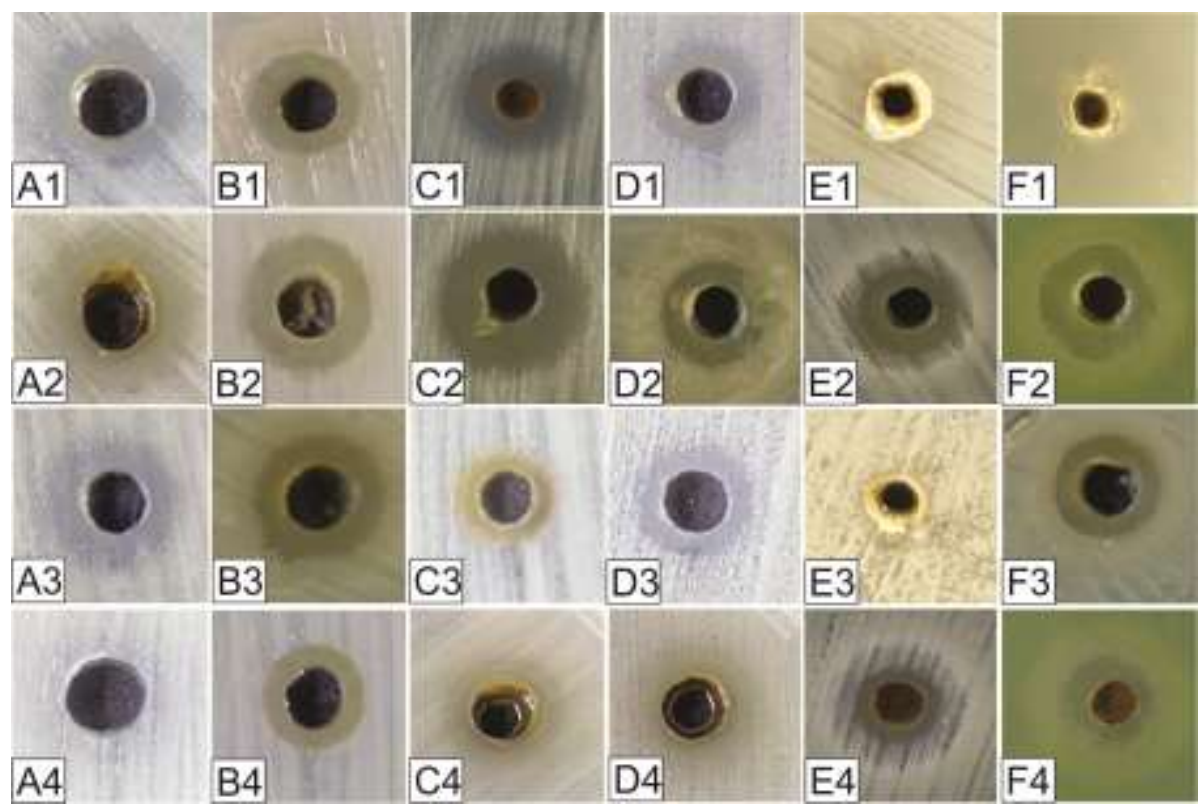

Figure 2. Inhibition zone of bilimbi extracts against MDR bacteria: (A) ES $\beta$ L K. pneumoniae ssp pneumonia; (B) ES $\beta$ L E. coli; (C) ES $\beta$ L + CRE, E. coli; (D) ES $\beta$ L + CRE, K. pneumoniae ssp pneumonia; (E) MRSA; (F) $\mathrm{ES} \beta \mathrm{L}+\mathrm{CR}$ P. aeruginosa, and solvent (1) chloroform; (2) ethanol; (3) methanol; (4) water

Table 2. Diameters of inhibition zone of bilimbi fruit extract $(100 \mathrm{mg} / \mathrm{mL})$ with various solvents against clinical isolates of MDR bacteria (mm)

\begin{tabular}{|c|c|c|c|c|c|c|}
\hline Solvent & $\begin{array}{c}\mathrm{ES} \beta \mathrm{L} \\
\text { K. pneumoniae } \\
\text { ssp. pneumoniae }\end{array}$ & $\begin{array}{l}\text { ES } \beta \mathrm{L} \\
\text { E. coli }\end{array}$ & $\begin{array}{l}\mathrm{ES} \beta \mathrm{L}+ \\
\mathrm{CRE} \text { E. } \\
\text { coli }\end{array}$ & $\begin{array}{c}\mathrm{ES} \beta \mathrm{L}+\mathrm{CRE} K . \\
\text { pneumoniae ssp. } \\
\text { pneumonia }\end{array}$ & MRSA & $\begin{array}{l}\mathrm{ES} \beta \mathrm{L}+\mathrm{CR} \text { Pseu- } \\
\text { domonas aerugino- } \\
\text { sa }\end{array}$ \\
\hline Chloroform & 6 & 10.5 & 11 & 8.5 & - & - \\
\hline Ethanol & 10 & 10.5 & 14.5 & 10 & 11.5 & 13.5 \\
\hline Methanol & 8 & 10.5 & 7 & 10 & - & 8.5 \\
\hline Water & - & 9 & 9.5 & 8.5 & 10 & 11.5 \\
\hline
\end{tabular}


The extracts exhibited inhibition zone ranging from $6 \mathrm{~mm}$ to $14.5 \mathrm{~mm}$ diameter, with the most noteworthy results shown by ethanol solvent. The ethanolic extract of the bilimbi fruit showed inhibition zones ranging from $10-14.5 \mathrm{~mm}$ against the clinical strains of all strain test. These results are in accordance with the research report bay Valle-Jr et al. (2015) that, the ethanolic extract $P$. betle leaf demonstrated inhibition zones against MRSA, ESBL-Enterobacteriaceae and non Enterobacteriaceae. The methanolic extract of bilimbi fruit demonstrated inhibition zones of 7-10.5 $\mathrm{mm}$ against the Gram-negative bacteria of all strain test, but not at MRSA (Gram positive). In other study, the methanolic extract of Albizia adianthifolia, Alchornea laxiflora, Laportea ovalifolia demonstrated inhibition zones against MDR Gram-negative bacteria (Tchinda et al., 2017). The water extract of bilimbi fruit demonstrated inhibition zones of $8.5-11.5 \mathrm{~mm}$ against all strain test, but not at $K$. pneumonia. The growths of $K$. pneumoniae were not inhibited by all the extracts of Ocimum gratissimum, Vernonia amygdalina and Aframomum melegueta with water solvent that inhibit the other Enterobacteriaceae (Alo et al., 2012). The chloroform extract of Bilimbi fruit demonstrated inhibition zones of 6-11 mm against all of strain test, but not at $S$. aureus and P. aeruginosa. In other study, the chloroform extract of Streptomyces sp. strain Al-Dhabi-97 isolated from the marine could not inhibit S. aureus (Al-dhabi et al., 2020) and the chloroform extract of seed of Callistemon lanceolatus could not inhibit $P$. aeruginosa (Khavitha and Satish, 2014). Results of the antibacterial assays showed that the most commonly inhibited bacteria by the ethanolic plant extracts were the clinical ES $\beta \mathrm{L}+\mathrm{CRE}, E$. coli, ES $\beta \mathrm{L}+\mathrm{CR} P$. aeruginosa, MRSA, ES $\beta \mathrm{L} E$. coli, ES $\beta \mathrm{L}$ K. pneumoniae ssp pneumonia, ES $\beta \mathrm{L}+$ CRE, K. pneumoniae ssp pneumonia

\section{Minimum bactericidal boncentration (MBC) of the fruit extracts.}

The antibacterial activity of the four extracts were assayed in vitro by the agar microdilution method against six resistant bacteria. The antibacterial activity against each bacterium was observed to be varied. Table 3 shows that the all bilimbi extracts exhibited inhibition of bacterial growth against MDR bacteria $(12.5-50 \mathrm{mg} / \mathrm{mL})$. Table 3 shows that all bilimbi extracts exhibited lower MBC values than Cefazolin against ESBL strains and lower than Sulfamethoxazole against MRSA. This showed that extract of bilimbi have the potential to be developed as antibacterial agents for MDR bacteria. The microdilution method was used in the present study because it is a quantitative reference method routinely used in clinical laboratories.

Furthermore, all extracts showed highly varying MBC values against MDR bacteria, but the lowest MBC value belonged to water extract $(12.5 \mathrm{mg} / \mathrm{mL})$ against ES $\beta \mathrm{L}+\mathrm{CR}$ P. aeruginosa. Aqueous extract of the truffle Terfezia claveryi contains a potent antimicrobial agent toward $P$. aeruginosa (Janakat et al., 2005). In the present study, favorable antagonistic activities against various MDR bacteria were exhibited by the all extract of bilimbi. However, this study resolutely established the ethanolic fruit extract of bilimbi exhibiting wide zones of growth inhibition against MDR bacteria tested. Preliminary phytochemical studies of the fruit extracts using chemical methods and thin layer chromatography (TLC) revealed the presence of flavonoids, tannins, and terpenes (Hasanuzzaman et al., 2013; Patil et al., 2013).

Table 3. MBC of of bilimbi fruit extract against clinical isolates of MDR bacteria (mg/mL).

\begin{tabular}{|c|c|c|c|c|c|c|}
\hline Solvent & $\begin{array}{l}\text { ES } \beta \mathrm{L} K . \text { pneu- } \\
\text { moniae ssp } \\
\text { pneumoniae }\end{array}$ & $\begin{array}{c}\text { ES } \beta \mathrm{L} \\
\text { E. coli }\end{array}$ & $\begin{array}{c}\text { ES } \beta \mathrm{L}+ \\
\text { CRE, } \\
\text { E. coli }\end{array}$ & $\begin{array}{c}\text { ES } \beta \mathrm{L}+\mathrm{CRE} K . \\
\text { pneumoniae ssp } \\
\text { pneumonia }\end{array}$ & MRSA & $\begin{array}{c}\text { ES } \beta \mathrm{L}+\mathrm{CR} \\
\text { Pseudomonas } \\
\text { aeruginosa } \\
\end{array}$ \\
\hline Chloroform & 50 & 25 & 50 & 50 & 25 & 25 \\
\hline Ethanol & 25 & 50 & 50 & 25 & 25 & 25 \\
\hline Methanol & 50 & 50 & 50 & 50 & 25 & 25 \\
\hline Water & 25 & 25 & 50 & 50 & 50 & 12.5 \\
\hline Cefazolin & 64 & 64 & 64 & 64 & - & 64 \\
\hline Meropenem & 0.25 & 0.25 & - & - & - & - \\
\hline Tigecycline & - & - & 0.5 & 1 & - & 8 \\
\hline Sulfamethoxazole & - & - & - & - & 320 & - \\
\hline Vancomycin & - & - & - & - & 1 & - \\
\hline
\end{tabular}

The antibacterial activity of the plant can be attributed to its phytochemical compounds. Phytochemical compounds act as shields against disease infec- tions. The most important phytochemicals are tannins, flavonoids, alkaloids, and terpenes (Kumar et al., 2013). Flavonoids (Khalid et al., 2019), tannins 
(Shahat and Marzouk, 2013), and terpenes (Broniatowski and Mastalerz, 2015) have been recognized to exhibit quite potent antibacterial activity. The mechanism of antibacterial activity of flavonoids, tannins, and terpenes compound in the bilimbi is unknown. However, according to (Abuga et al., 2020), phytochemical compounds can inhibit the growth of bacteria by destruction of the becterial cell wall. The fruit of bilimbi was shown to be potentially developed as antibacterial agents, especially for MDR strains. Further in vivo research and discovery of action modes are needed to shed light on its antibacterial effects. so that potential clinical drug and health products could be developed. This study can provide new information about the benefits of bilimbi as a source of natural antibacterial against MDR bacteria.

\section{CONCLUSION}

The fruit of bilimbi was shown to be potentially developed as antibacterial agent, especially for MDR strains. The ethanolic extract showed the highest antibacterial activity against the all MDR bacterial test in the agar well diffusion assay (10-14.5 mm inhibition diameter). The MBC of bilimbi water extract against ES $\beta \mathrm{L}+\mathrm{CR}$ Pseudomonas aeruginosa showed the best antibacterial activity $(12.5 \mathrm{mg} / \mathrm{mL})$.

\section{REFERENCES}

Abuga, I., Fariza, S., Abdul, R., Leong, K., Syaiful, M., Abdull, B. (2020). European Journal of Integrative Medicine In vitro antibacterial effect of the leaf extract of Murraya koenigii on cell membrane destruction against pathogenic bacteria and phenolic compounds identification. Eur. J. Integr. Med. 33, 101010.

Ahmad, W.N.A.W., Mahmoda, N.H., Ali, A.M., (2019). A Review of Medicinal Plants and Daily Foods used in Southeast Asia Possessing Antidiabetic Activity. J. Agrobiotech 10(1), 1735.

Akhtar, N. (2015). Phytochemical analysis and comprehensive evaluation of antimicrobial and antioxidant properties of 61 medicinal plant species. Arab. J. Chem.

Al-dhabi, N.A., Esmail, G.A., Ghilan, A.M., Arasu, M.V., Duraipandiyan, V., Ponmurugan, K. (2020). Chemical constituents of Streptomyces $\mathrm{sp}$. strain Al-Dhabi-97 isolated from the marine region of Saudi Arabia with antibacterial and anticancer properties. J. Infect. Public Health 13, 235-243.

Ali, R., Hossain, M., Runa, J.F. (2014). Evaluation of thrombolytic potential of three medicinal plants available in Bangladesh, as a potent source of thrombolytic compounds. Avicenna J.
Phytomedicine, 4(6), 430-436.

Alo, M.., Anyim, C., Elom, M., Uchenna, D.S. (2012). Antibacterial activity of water, ethanol and methanol extracts of Ocimum gratissimum , Vernonia amygdalina and Aframomum melegueta. Adv. Appl. Sci. Res. 3(2), 844-848.

Andleeb, S., Alsalme, A., Al-zaqri, N., Warad, I., Alkahtani, J., (2020). In-vitro antibacterial and antifungal properties of the organic solvent extract of Argemone mexicana L . J. King Saud Univ. - Sci. 1-6.

Aumeeruddy-elalfi, Z., Gurib-fakim, A., Mahomoodally, F. (2015). Antimicrobial, antibiotic potentiating activity and phytochemical profile of essential oils from exotic and endemic medicinal plants of Mauritius. Ind. Crop. Prod. 71, 197-204.

Ballani, K., Babby, J. (2016). Antimicrobial Resistance: Highlights of New Antibiotics for Organisms. J. Nurse Pract. 12, 354-355.

Broniatowski, M., Mastalerz, P. (2015). Biochimica et Biophysica Acta Studies of the interactions of ursane-type bioactive terpenes with the model of Escherichia coli inner membrane - Langmuir monolayer approach 1848, 469-476.

CLSI, (2018). M07: Methods for Dilution Antimicrobial Susceptibility Tests for Bacteria That Grow Aerobically, 11th Edition.

Dnyaneshwar, M., Shekhar, B., Shaijesh, S., Juvekar, R. (2010). Hepatoprotective effect of Averrhoa bilimbi Linn. agains carbon tetrachloride induced hepatic damage in rats. Pharmacologyonline 3, 1-6.

Hasanuzzaman, M., Ali, M.R., Hossain, M., Kuri, S., Islam, M.S. (2013). Evaluation of total phenolic content, free radical scavenging activity and phytochemical screening of different extracts of Averrhoa bilimbi (fruits). Int. Curr. Pharm. J. 2(4), 92-96.

Janakat, S., Al-Fakhir, S., Sallal, A. (2005). Evaluation of antibacterial activity of aqueous and methanolic extracts of the truffle Terfezia claveryi against Pseudomonas. Saudi Med J, 26, 952-5.

Khalid, M., Bilal, M., Dan-feng, H. (2019). Role of flavonoids in plant interactions with the environment and against human pathogens - A review. J. Integr. Agric. 18(1), 211-230.

Khavitha, K.., Satish, S. (2014). Antibacterial activity of seed extract of Callistemon lanceolatus DC on urophatogenic bacteria. J. acute Med. 4, 612.

Kumar, S.R., Loveleena, D., Godwin, S. (2013). Medicinal Property of Murraya Koenigii - A Review. Int. Res. J. Biol. Sci. 2(9), 80-83.

Lestari, S.D., Sadiq, A.L.O., Safitri, W.A., Dewi, 
S.S., Prastiyanto, M.E. (2019). The antibacterial activities of bacteriocin Pediococcus acidilactici of breast milk isolate to against methicillinresistant Staphylococcus aureus. J. Phys. Conf. Ser. 1375, 012021.

Mekes, A. El, Zahlanea, K., Said, L.A., Ouafi, A.T., Barakate, M. (2019). The clinical and epidemiological risk factors of infections due to multi-drug resistant bacteria in an adult intensive care unit of University Hospital Center in Marrakesh-Morocco. J. Infect. Public Health, 13(4), 637-643

Mohamad, S., Zin, N.M., Wahab, H.A., Ibrahim, P., Sulaiman, S.F., Zahariluddin, A.S.M., Noor, S.S.M., 2011. Antituberculosis potential of some ethnobotanically selected Malaysian plants. $J$. Ethnopharmacol. 133, 1021-1026.

Ngameni, B., Fotso, G., Kamga, J., Ambassa, P., Abdo, T., Fankam, A., Voukeng, I., Ngadjui, B., Abegaz BM, K. V. (2013). 9-Flavonoids and related compounds from the medicinal plants of Africa. Chem. Pharmacol. 301-350.

Parvez, M.A.K., Saha, K., Rahman, J., Munmun, R.A., Rahman, M.A., Dey, S.K., Rahman, M.S., Islam, S., Hossain, M., Shariare. (2019). Heliyon Antibacterial activities of green tea crude extracts and synergistic effects of epigallocatechingallate (EGCG) with gentamicin against MDR pathogens. Heliyon 5, e02126.

Patil, A.G., Koli, S.P., Patil, D.A. (2013). Pharmcognostical standardization and HPTLC fingerprint of Averrhoa bilimbi (L.) fruits. $J$. Pharm. Res. 6, 145-150.

Prastiyanto, M., Darmawati, S., Setyaningtyas, A., Trisnawati, L., Syafira, A. (2016). Antimicrobial Activity and Identification The Compounds of Methanol Extract from The Pleurotus Ostreatus Fruiting Body. El-Hayah, 6(1), 29-34.

Ryandini, D., Pramono, H., Sukanto. (2018). Antibacterial Activity of Streptomyces SAE4034 Isolated from Segara Anakan Mangrove Rhizosphere against Antibiotic Resistant Bacteria. Biosaintifika, 10(1), 117-
124.

Seebaluck-sandoram, R., Lall, N., Fibrich, B., Blom, A., Staden, V., Saleem, H., Fawzi, M., 2019. Biocatalysis and Agricultural Biotechnology Antimicrobial, antioxidant and cytotoxic evaluation of two underutilised food plants: Averrhoa bilimbi L. (Oxalidaceae) and Phyllanthus acidus L . Skeels (Phyllanthaceae). Biocatal. Agric. Biotechnol. 18, 100998.

Shahat, A.A., Marzouk, M.S. (2013). 13 Tannins and Related Compounds from Medicinal Plants of Africa, Medicinal Plant Research in Africa. Elsevier Inc. https://doi.org/10.1016/B978-0-12405927-6.00013-8

Tchinda, C.F., Voukeng, I.K., Veronique, P., Kuete, V. (2017). Antibacterial activities of the methanol extracts of Albizia adianthifolia, Alchornea laxiflora, Laportea ovalifolia and three other Cameroonian plants against multidrug resistant Gram-negative bacteria. Saudi $J$. Biol. Sci. 24, 950-955.

Tillah, M., Batubara, I., Sari, R.K. (2017). Antimicrobial and Antioxidant Activities of Resins and Essential Oil. Biosaintifika 9(1), 134-139.

Valle-Jr, D.L., Andrade, J.I., Puzon, J.J.M., Cabrera, E.C., Rivera, W.L. (2015). Antibacterial activities of ethanol extracts of Philippine medicinal plants against multidrug-resistant bacteria. Asian Pac. J. Trop. Biomed. 5, 532540.

Wahyuni, R.A., Putri, I.Y., Jayadi, E.L., Prastiyanto, M.E. (2019). Aktivitas Antibakteri Ekstrak Buah Parijoto (Medinilla speciosa) terhadap bakteri Extended Spectrum Betalactamase (ESBL) Escherichia coli dan Methicillin Resistant Staphylococcus aureus (MRSA). J. Media Anal. Kesehat. 10, 106-118.

Word Health Organization, 2018. Resistance in bacteria Antibiotic [WWW Document]. URL http://www.who.int/mediacentre/factsheets/fs19 4/en/ (accessed 4.9.18). 